\title{
(6) OPEN ACCESS \\ Case ascertainment of heat illness in the British Army: evidence of under-reporting from analysis of Medical and Command notifications, 2009-2013
}

\author{
Michael J Stacey, ${ }^{1,2}$ S Brett, ${ }^{1,3}$ D Woods, ${ }^{2,4}$ S Jackson, ${ }^{5}$ D Ross ${ }^{5}$
}

\begin{abstract}
${ }^{1}$ Department of Surgery and Cancer, Imperial College, London, UK

${ }^{2}$ Department of Military Medicine, Royal Centre for Defence Medicine, Birmingham, UK ${ }^{3}$ Hammersmith Hospital, Du Cane Road, Greater London, UK

${ }^{4}$ Carnegie Research Institute, Leeds Beckett University, Leeds, UK

${ }^{5}$ Army Health Unit, Army Medical Directorate, Camberley, UK
\end{abstract}

\section{Correspondence to} Maj Michael John Stacey, Department of Surgery and Cancer, Imperial College, Hammersmith Hospital, Du Cane Road, London W120HS, UK

M.stacey13@imperial.ac.uk

Received 14 November 2014 Revised 13 January 2015 Accepted 14 January 2015 Published Online First 24 February 2015

\section{CrossMark}

To cite: Stacey MJ, Brett S,
Woods D, et al. J R Army
Med Corps 2016;162:428-
433 .

\section{ABSTRACT}

Background Heat illness in the Armed Forces is considered preventable. The UK military relies upon dual Command and Medical reporting for case ascertainment, investigation of serious incidents and improvement of preventive practices and policy. This process could be vulnerable to under-reporting.

Objectives To establish whether heat illness in the British Army has been under-reported, by reviewing concordance of reporting to the Army Incident Notification Cell (AINC) and the Army Health Unit (AHU) and to characterise the burden of heat illness reported by these means.

Methods Analysis of anonymised reporting databases held by the AHU and AINC, for the period 2009-2013.

Results 565 unique cases of heat illness were identified. Annual concordance of reporting ranged from $9.6 \%$ to $16.5 \%$. The overall rate was $13.3 \%$. July was the month with the greatest number of heat illness reports $(24.4 \%$ of total reporting) and the highest concordance rate $(30 \%)$. Reports of heat illness from the UK $(n=343)$ exceeded overseas notifications $(n=221)$ and showed better concordance $(17.1 \%$ vs $12.8 \%)$. The annual rate of reported heat illness varied widely, being greater in full-time than reservist personnel (87 vs 23 per100 000) and highest in full-time untrained personnel (223 per100 000).

Conclusions The risk of heat illness was global, yearround and showed dynamic local variation. Failure to dualreport casualties impaired case ascertainment of heat illness across Command and Medical chains. Current preventive guidance, as applied in training and on operations, should be critically evaluated to ensure that risk of heat illness is reduced as low as possible. Clear procedures for casualty notification and surveillance are required in support of this and should incorporate communication within and between the two reporting chains.

\section{INTRODUCTION}

The Joint Service Publication on Climatic Injuries in the Armed Forces (JSP 539) uses 'heat illness' to describe incapacitation resulting from a rise in core body temperature. Most episodes are considered preventable. ${ }^{1}$ Notification of military heat illness casualties is crucial to effective force protection and a dual mechanism of Command and Medical reporting applies across the breadth of service activities, in the both Firm Base and overseas. Since its publication in 2003, JSP 539 has directed military doctors to notify Army cases of heat illness to the Army Health Unit (AHU), using a Heat Illness Medical Reporting Form delivered by post or by fax. This has facilitated aetiological and epidemiological analysis of heat illness and informed medical significant event reporting. Under UK statute, the Army is also required to notify any episode of heat-induced illness as a workplace incident. ${ }^{2}$ Commanders must return a completed Ministry of Defence (MoD) Form 510 Accident Report to the Army Incident Notification Cell (AINC), ${ }^{3}$ which operates under the jurisdiction of the Chief Environment and Safety Officer (CESO), Army, and sits with the Land Accident Investigation Team (LAIT) at Army Headquarters. Serious cases of heat illness should also be notified to Defence Primary Healthcare (DPHC) in the Firm Base and to Permanent Joint Headquarters (PJHQ) for operational deployments (Box 1).

Two decades have passed since the burden of UK military heat illness was systematically surveyed..$^{4-6}$ Dickinson ${ }^{4}$ used discharge coding from military hospital episodes to identify 1448 personnel affected by heat illness in all three services between 1981 and 1994. The British Army rate was determined to be 71 per 100000 personnel or 118 hospitalisations per year and included 11 fatalities attributable to the effects of heat $(0.6$ per 100000 personnel or one death per year). During the same period, the ratio of hospitalised to non-hospitalised (ambulatory) cases was approximately 7:3 for army heat illness reported in the UK. ${ }^{5}{ }^{6}$ Following a review of preventive practices and changes in Defence policy, the incidence of heat illness was thought to have fallen ${ }^{7}$ and the

Box 1 Examples of serious heat illness incidents that require Medical notification to Defence Primary Healthcare or Permanent Joint Headquarters ${ }^{1}$

A. Any fatality.

B. Any hospitalisation for clinical reasons for climatic injury.

C. Any aeromedical evacuation for climatic injury.

D. Any incidence of climatic injury sufficient to require downgrading.

E. Any incident involving multiple climatic casualties.

F. Any individual suffering recurrent climatic injury (as a distinct repeat event, not part of the same initial episode).

G. Any unusual or atypical events (eg, climatic casualties occurring when the risk assessment deemed this unlikely). 
Surgeon General's Heat Illness Working Group (SG's HIWG) was established to regularly review and update the guidance in JSP 539, using subject matter experts drawn from across the UK military.

Yet life-threatening and fatal cases of heat illness have continued to affect the Army in training ${ }^{9}$ and on deployed operations. ${ }^{10}$ Though high-profile incidents may lead to improvements in awareness and reporting practices, it has been suggested that heat illness remains under-reported in the modern era. ${ }^{11}$ This view is supported by evidence of under-reporting in other contemporaneous disease surveillance systems and from the deployed environment in Afghanistan. ${ }^{12} 13$ To address this issue, heat illness notifications to the AHU and AINC were examined for the 5-year period 2009-2013. The primary aim was to determine the proportion of casualties notified to both Command and Medical chains, that is, the concordance of reporting. The secondary aim was to characterise the burden of suspected heat illness, by identifying when, where and to what extent different parts of the army were affected. It was not intended to evaluate the absolute number of heat illness cases diagnosed in the UK military, which is a task undertaken annually by Defence Statistics Health (DSH). A definitive analysis of worldwide hospitalisation rates, requiring information from disparate civilian and military secondary care providers, was also beyond the scope of the study.

\section{METHODS}

The permission of the British Army Caldicott Guardian was secured for a secondary analysis of databases held by the AHU and AINC. The databases were anonymised and searched to identify all reports of suspected heat illness affecting Army personnel between 1 January 2009 and 31 December 2013. Reservist personnel from the Volunteer and Regular Reserves were included in the analysis; those from the Sponsored Reserve and University Officer Training Corps were not.

For each report the date, referring unit and location of the incident were recorded, in addition to details of the casualty's military unit, the activity being undertaken at the time of the incident and any clinical treatment provided or outcome such as first-aid provision or hospital emergency department attendance. Where incidents had occurred around the same time $( \pm 72 \mathrm{~h})$ and in similar circumstances, military Service numbers were requested and compared so that identical episodes of heat illness would not be included twice in the analysis. A separate check of Service numbers was conducted to assess for disease recurrence, defined as a second episode of heat illness occurring within 60 days of the index episode. ${ }^{14}$

Descriptive data were summarised for the composite series. Reports were categorised as from training (TNG), field (FLD) or operationally deployed (DEP) units. The time and the location of the incident were specified, by month, year and geographical/ strategic region. Reports concerning full-time Army personnel, including Gurkhas and individuals in the Full Time Reserve Service, were denoted FULL. Reports concerning members of the Army Reserve, including the Regular Reserve and the Volunteer Reserve (formerly known as the Territorial Army), were denoted A-RES. Reports were also differentiated according to the casualty's training status. Recruit (RCT) referred to someone undergoing initial or special-to-Arm/Service training and included Officer Cadets at the Royal Military Academy Sandhurst. Only TNG notified RCT casualties, whereas trained personnel were employed in all referring locations, including TNG. Where reporting information had been omitted, 'not reported' (NR) was the category assigned.

\section{RESULTS}

The AHU database contained 326 Medical reports of heat illness. Five of these described an individual affected by heat illness for the second time during the period surveyed, but only one report met criteria for recurrence and the others were retained for analysis. The AINC database contained 315 Command notifications of heat illness and no episodes of recurrence. Concordance of reporting to the AHU and AINC was seen in 75 cases (150 of 651 reports), the details of which were merged to generate a composite series of 565 unique cases. Concordance ranged from $9.6 \%$ to $16.5 \%$ in each year and the overall rate was $13.3 \%$.

Figure 1A shows annual reporting submitted to the AHU only, to the AINC only or to both. The average number of heat illness reports was 113 and varied from 83 reports in 2012 to 147 reports in 2010. Figure $1 \mathrm{~B}$ displays total reports by month. The month of July saw the greatest number of heat illness reports (138 cases or $24.4 \%$ of total reports) and the highest concordance in total reporting (30\%). The nadir of reporting was December, with two cases notified to the AHU alone. The highest frequency months were April to September inclusive, during which 465 notifications of heat illness were made (82.3\% of total reporting).

Figure 2A displays annual reporting of heat illness from the UK and non-UK (overseas) locations. In the composite series, 343 reports originated in the UK (60.7\%), 221 reports came from overseas (39.1\%) and one location was not recoded. Concordance of reporting to the AHU and AINC was higher for cases that occurred in the UK than for heat illness notified from overseas $(17.1 \%$ vs $12.8 \%)$. Total reporting by year and region is displayed in Table 1.

Figure 2B, C displays monthly reporting by location for the years 2010 and 2013, respectively. In 2010, 71.6\% of heat illness was reported for the April to September period and half of cases were from overseas. By contrast, nearly three quarters
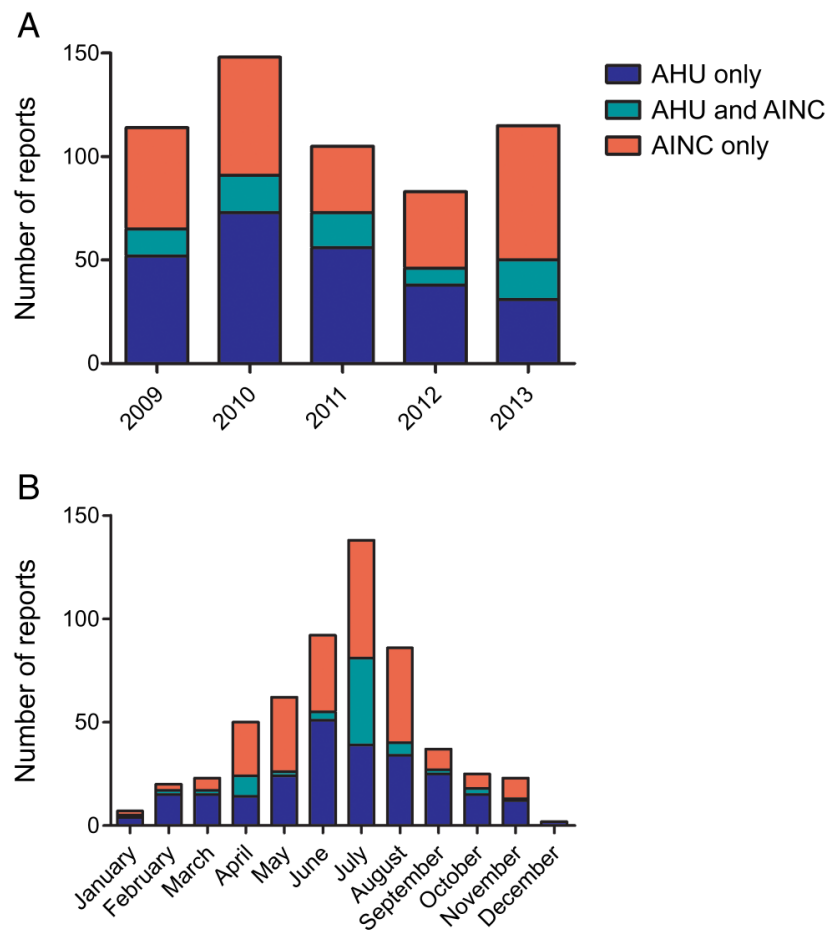

Figure 1 A total of 565 consecutive reports of heat illness to the Army Health Unit (AHU) and Army Incident Notification Cell (AINC), 20092013. Displayed by (A) year and (B) month. 
A

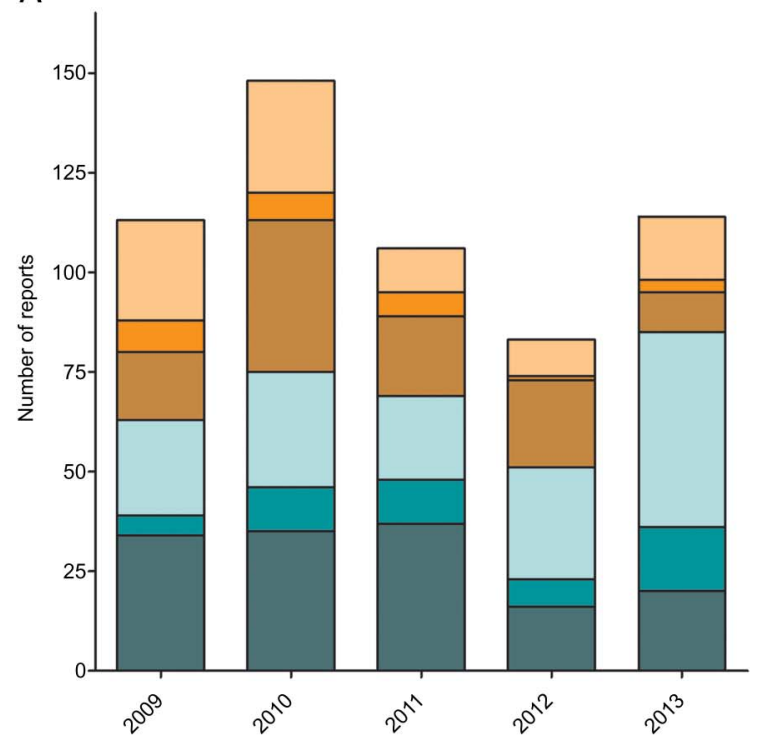

C

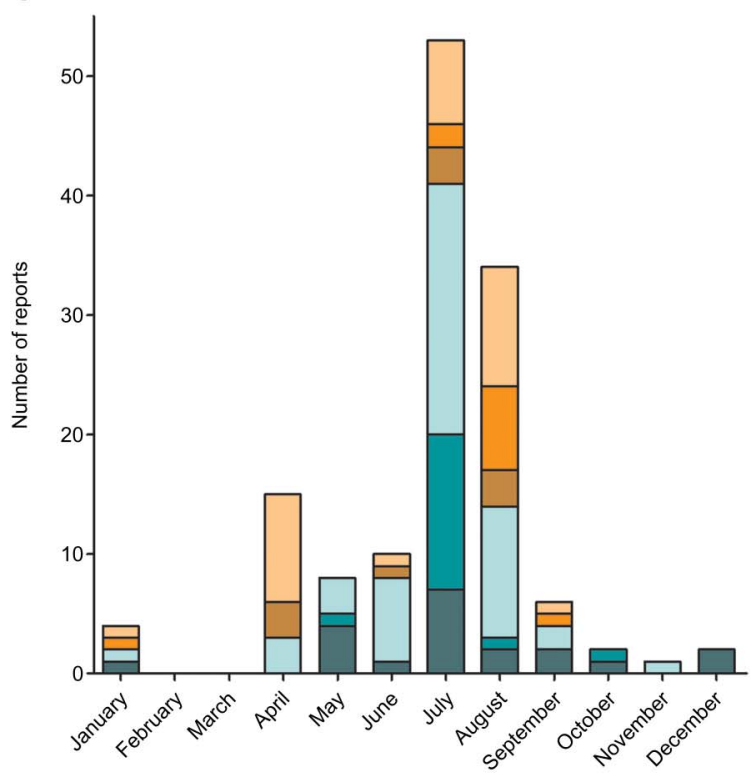

B

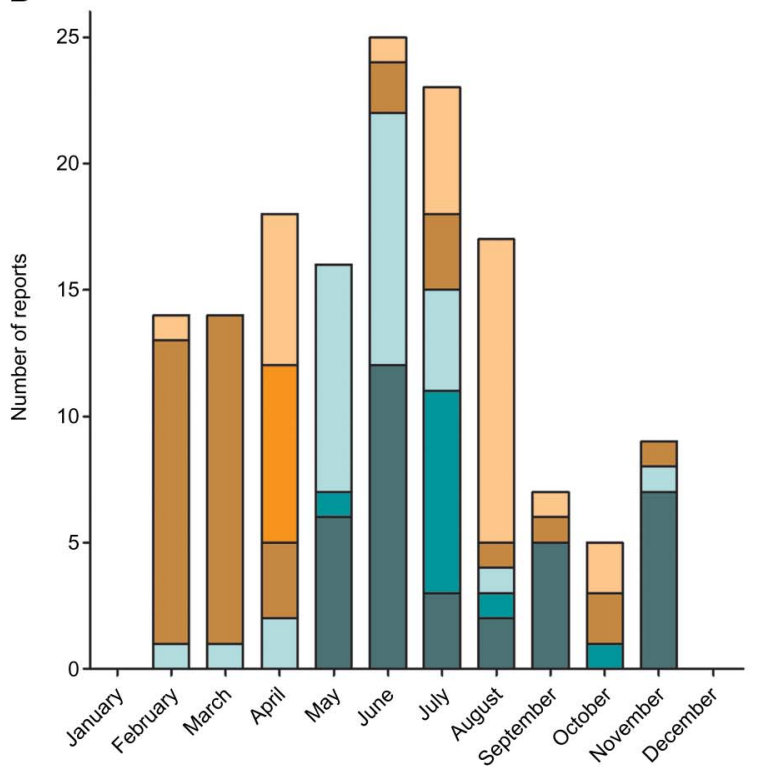

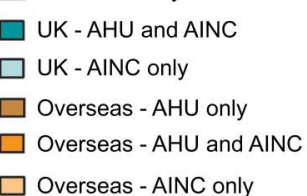

Figure 2 Heat illness reporting (UK vs overseas): (A) annual reporting, 2009-2013, (B) monthly reporting, 2010 and (C) monthly reporting, 2013. AHU, Army Health Unit; AINC, Army Incident Notification Cell; NR, not reported.

of 2013 reporting described UK incidents and April to September accounted for $93.0 \%$ of total notifications.

Heat illness from TNG accounted for $62.8 \%$ of total reports and affected untrained (RCT) personnel as well as trained, such as permanent staff and those held temporarily on strength for selection, promotion and specialist courses. Reporting from FLD (28.5\%) and DEP (6.0\%) described trained casualties only. All DEP notifications came from Southern Afghanistan. Reporting by TNG demonstrated greater concordance (16.1\%) than reporting by FLD (10.6\%) and by DEP (0\%).

Annual reporting rates for heat illness are presented by military employment category in Figure 3. Concordance was similar between FULL and A-RES cases (12.3\% vs $12.9 \%)$. At the time of writing, adequate 5 -year manning statistics were available for trained and untrained FULL strengths. ${ }^{15}$ Complete denominator data for A-RES were available for 2012 and 2013 only and did not differentiate training status. ${ }^{16}$ Excluding A-RES reports from 2009 to 2011 and reports where employment status was $\mathrm{NR}$, the 5 -year rate of suspected heat illness was 76 cases per 100000 Army personnel. For the years 2012 and 2013, the respective rates were 50 and 72 per 100000 Army personnel. The annual rate of reported heat illness varied widely with the population at risk, however, from 21 per 100000 (A-RES in 2012) up to 253 per 100000 (FULL untrained strength in 2013). Annual reporting rates were greater in FULL than in A-RES personnel (87 vs 23 per 100000 ) and, in the FULL population, greater for the RCT than the trained strength (223 vs 59 per 100000 ).

\section{DISCUSSION}

This evaluation of Army-wide heat illness reporting is the first to appear in the literature since preventive practices were reviewed in the mid-1990s. Since then, epidemiological reports of heat illness in the UK military have been limited to shorter 
Table 1 Total heat illness reporting to the AHU and AINC (2009-2013), by region of incident: Afghanistan (AFG), Brunei, Asia and the Middle East (BRU), Cyprus and Southern Europe (CYP), Germany (GER), North America (NAM), Sub-Saharan Africa (SSA) and United Kingdom (UK)

\begin{tabular}{lcccccr}
\hline Location & $\mathbf{2 0 0 9}$ & $\mathbf{2 0 1 0}$ & $\mathbf{2 0 1 1}$ & $\mathbf{2 0 1 2}$ & $\mathbf{2 0 1 3}$ & Total \\
\hline AFG & 16 & 7 & 9 & 2 & 0 & 34 \\
BRU & 5 & 25 & 0 & 10 & 5 & 45 \\
CYP & 9 & 4 & 6 & 3 & 6 & 28 \\
GER & 5 & 10 & 5 & 6 & 8 & 34 \\
NAM & 10 & 13 & 10 & 8 & 10 & 51 \\
SSA & 5 & 14 & 6 & 3 & 0 & 28 \\
UK & 63 & 75 & 69 & 51 & 85 & 343 \\
NR & 1 & 0 & 0 & 0 & 1 & 2 \\
\hline AHU, Army Health Unit; AINC, Army Incident Notification Cell; NR, not reported.
\end{tabular}

case series of troops hospitalised and confined during training ${ }^{17}$ and operations in the Middle East. ${ }^{18-22}$ While these accounts reflect major operational commitments at the beginning of the 21 st century, our results suggest they should be considered in a wider reporting context, with hospitalisations on deployment making up only part of the overall picture.

This is also the first heat illness review to be published since the introduction in 2007 of electronic primary care records, which are now the primary means for identifying heat illness to DSH. The requirement for single service reporting was phased out in 2014 and the AHU presently receives Heat Illness Medical Reporting Forms only where incidents cannot be electronically recorded within 28 days. These evolving changes may have affected how the Medical decision to report was applied in 2013, resulting in under-reporting of heat illness to the AHU and perhaps contributing to our key finding: that concordance of heat illness notifications to the AHU and AINC was poor. Between January 2009 and December 2013, a comparable number of suspected heat illness cases were notified to each organisation (325 vs 315). Yet only 23\% of Medically reported casualties were notified to the AINC and the AHU was informed about just $24 \%$ of Command-notified incidents, resulting in a failure rate of $86.7 \%$ for dual reporting.

In general, concordance of reporting was greater where the volume of notified heat illness was higher, such as during the month of July, in training establishments and among recruits to the full-time Army. Heat illness casualties were notified in larger numbers from the UK than from overseas and UK cases were also more likely to be dual reported. Even in the bestperforming domains, dual reporting occurred in less than half of cases and peaked at just $40.5 \%$ in training reports from July 2013. Among referring units, the greatest overall concordance was seen in reporting from TNG, which also generated the greatest number reports. The higher rates of RCT heat illness in our series may therefore represent enhanced awareness of, and engagement with, reporting requirements in TNG, rather than truly increased risk of heat illness relative to FLD and DEP. There are other reasons to suspect this. Units that are responsible for the delivery of training are expected to model best practice, which would include compliance with reporting requirements, and key Command and Medical appointments in TNG are often assigned to personnel with greater experience and seniority than in FLD and DEP, which may also reinforce appropriate reporting.
A

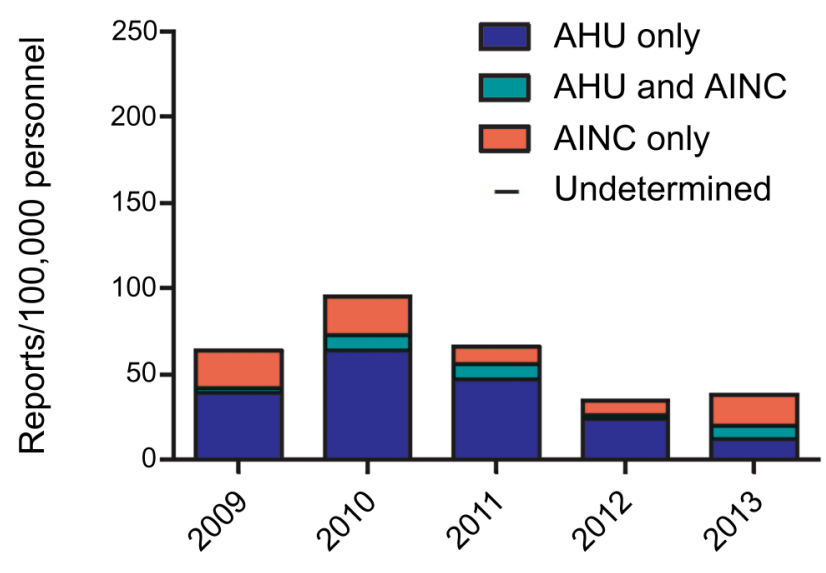

B

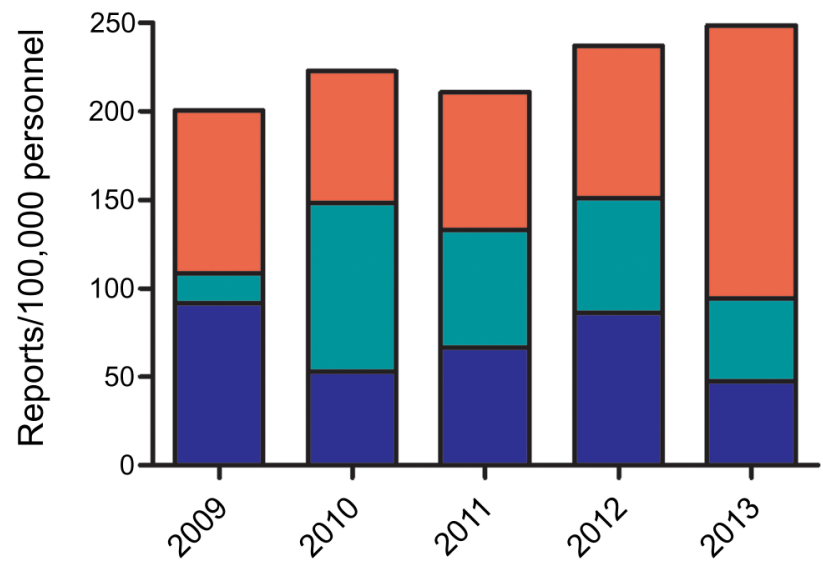

C

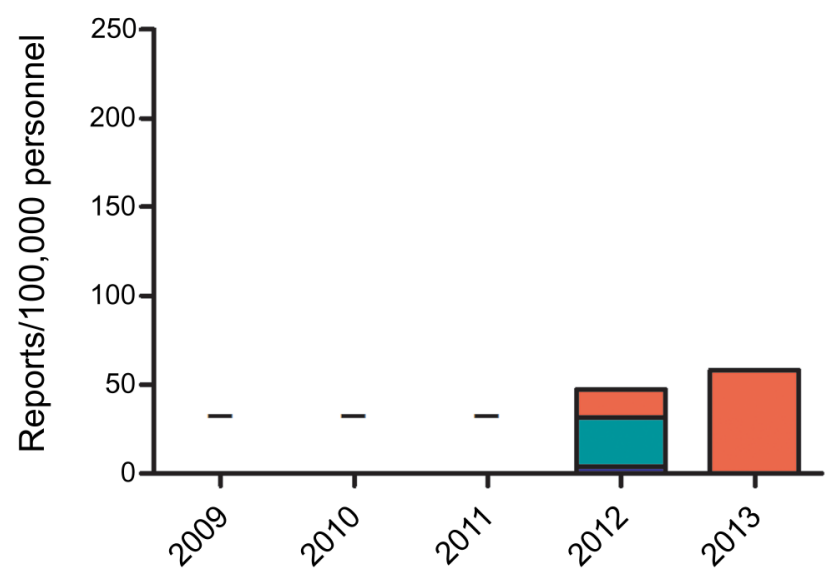

Figure 3 Annual rates of heat illness, 2009-2013 in (A) full-time (FULL) trained personnel, (B) FULL recruits and (C) members of the Army Reserve, trained and untrained strengths. AHU, Army Health Unit; AINC, Army Incident Notification Cell; NR, not reported.

Familiarity with the mechanisms available for reporting heat illness may have a greater impact upon adherence to this requirement than for notifiable disorders more commonly encountered in the military, such as gastrointestinal and respiratory tract infections. ${ }^{1323}$ It is likely that where cases are infrequently encountered, individuals will be less practised at recognising heat illness and will rightly err on the side of overdiagnosis. This is one of 
the reasons that we expect reporting to the AHU and the AINC to have included episodes of incapacity that masqueraded as heat illness, but were not, such as disturbances of metabolic or cardiac origin. Command notifications to the AINC are more likely to have featured this bias to over-reporting than those submitted by Medical personnel to the AHU, because of clinical acumen and additional information-such as ultimate patient outcomeavailable to the latter. But while overdiagnosis could account for cases notified to AINC but not to the AHU, this fails to explain why so many Medically notified heat illness episodes were NR by Commanders. An inputting back-log is known to have affected reporting to AINC for the 12-month period April 2012 to March $2013,{ }^{3}$ but would not account for the lack of concordance in preceding years. On the basis of this finding, Command ascertainment of heat illness must be considered subject to significant under-reporting bias. This raises concern for the ability of CESO (Army) to mitigate future heat illness by accident investigation, for the British Army to implement preventive strategies based on lessons learnt and for legislative requirements to be fulfilled satisfactorily.

Definitive clinical outcomes cannot be derived from the reporting data presented above, but published statistics from the past three financial years suggest that the historical 'hospitalised: ambulatory' ratio of $7: 3$ could reasonably be applied to our series. $^{24}$ This estimates the contemporary hospitalisation rate to be 60 cases per 100000 FULL personnel, which is only 11 fewer hospitalisations per 100000 personnel per year than in the 1981-1991 period. A more conservative figure of 38 hospitalisations per 100000 FULL personnel derives from Medical notifications only and provides a lower limit for the expected reduction in heat illness hospitalisations. Accepting either rate is a challenge to the view of military heat illness as a preventable disorder and calls into question the efficacy of the guidance provided in JSP 539, as presently applied by the British Army. Improving the accuracy of diagnosis for heat illness, both in ambulatory settings and in secondary care, would remove some of the confounding associated with overdiagnosis, such that reporting might better reflect the true Service burden of heat illness. In particular, diagnosis of cases where elevated core temperature was suspected, but not confirmed by measurement proximal to the point of incapacitation, would be aided by a test with high specificity for prior body heat storage. If a sensitive point-of-care solution could be developed in response to this challenge, the improved accuracy of diagnosis might also benefit Medical decision making and could help to improve clinical and occupational outcomes.

Like the majority of cases reported to the AHU and AINC, most episodes of heat illness arose during the Northern hemisphere summer. In the UK, average temperatures peak in July ${ }^{25}$ and this month accounted for a quarter of all notifications. Three heat-attributed deaths occurred on a military selection course in Wales during July 2013, ${ }^{26}$ which was the third warmest July on record. ${ }^{27}$ Both the AHU and AINC registered a high number of heat illness notifications from the UK that month and, while excess reporting may have arisen due to heightened awareness and overdiagnosis, true heat-related morbidity is also likely to have increased with the abrupt rise in environmental temperature at the beginning of the month. This followed extended winter conditions, the coldest Spring in 50 years and a cool June. ${ }^{28}$ Acclimatisation to a hot environment requires several days of activity in equivalent conditions, ${ }^{1}$ such that UK-based personnel would have been vulnerable to the first days of the heat wave. The future tactical $^{29}$ and strategic ${ }^{30} 31$ importance of the environment and extreme weather events is increasingly apparent and the need for dynamic assessment of the risk of heat illness must be emphasised. The events of July 2013 serve as a tragic reminder of historical heat illness commentary, that 'an average of one death per year...renders complacency impossible'. 8

Reporting from warmer climates was of greater significance in 2010, when annual notifications from the Brunei, Asia and the Middle East (BRU) surpassed any other overseas locations in any year of the series (Table 1). A significant number of Medically reported cases were associated with jungle training and selection courses in February and March (Figure 2B), but do not appear to have been Command notified. The reasons for this lack of concordance are unclear, though the arduous nature of training in BRU may have meant that unwell personnel were removed altogether from the training environment and from under local Command, via the Medical chain. Permanent TNG staff may have inadvertently overlooked the extant Accident Reporting requirement, meaning that AINC and LAIT were not alerted to incidents involving heat illness. The exact reasons for the excess of heat-related morbidity in BRU in 2010 are also unclear, but given that elevated heat and humidity are the norm for jungle training, the activity level and clothing state selected by Commanders would have warranted scrutiny. It is remarkable that in the following reporting year, 2011, there were no reports of heat illness at all from BRU. It is not known whether this reflected changes in local training or notification procedures, but in the absence of investigation by LAIT, the scope for Service-wide and Defence-wide learning and improved prevention would have been very limited. More recent Medical reporting of heat illness from BRU has been exemplary and has shown evidence of liaison with local Commanders, including confirmation that an Accident Report (MoD Form 510) has been sent and LAIT appropriately involved. Cross-checking of this nature should be integrated into future iterations of the electronic Medical template and Commanders should be encouraged to ensure that Medical personnel are also made aware of less severe cases that, for whatever, reason, do not present formally for clinical assessment.

Finally, comparison of reporting rates between FULL and A-RES was limited by non-availability of key information for the period addressed by the study, including the known strength of A-RES. For the years 2012 and 2013, denominator data were available for both FULL and A-RES (Regular and Volunteer) strengths. Less than $2 \%$ of notifications in the series concerned Regular Reservists, who are former FULL personnel retaining a liability to be called-up in times of service need. The incorporation of this large group, which may be exposed to relatively little military activity, likely had a dilutional effect upon the risk of heat illness calculated for A-RES. It will also have impacted on the overall Army rates, which would be higher if the denominator was restricted to those actively engaged in Army duties. The relatively low incidence of heat illness in A-RES may also reflect under-reporting to the AHU, as the majority of A-RES cases in the series were Command notified. As Reservist roles expand and mature within the Force, it is important that Medical providers to the A-RES are fully conversant with all aspects of JSP 539, including requirements for reporting heat illness.

\section{CONCLUSIONS}

Heat illness poses a persisting threat to the British Army. It has the capacity to degrade operational effectiveness by causing 
morbidity and occasional mortality in all environments and among all sectors of the Force, including Reservists and recruits. The dual mechanism of Command and Medical notification exists to reduce the risk of future heat illness, by identifying how preventive practices can be improved and policy implemented. Accurate and timely information must be provided to each reporting chain to fulfil the Command requirements of legislative compliance and accident investigation and the Medical functions of epidemiological surveillance and aetiological analysis. Reporting requirements have been clarified in this article.

We have also shown that Command and Medical systems under-report heat illness when applied in isolation and we suggest better integration as a means to their improvement. At unit level, Commanders and Medical personnel should communicate to ensure that heat illness casualties are mutually notified to AINC, DSH and DPHC/PJHQ. This process could be supported by including formal confirmation of the Command/ Medical interaction in the submission of heat illness reports. The organisations tasked with receiving and acting upon this reporting should also maintain open lines of communication and use established fora, such as SG's HIWG, to optimise surveillance for heat illness. The responsibility for promulgating and supporting up-to-date Medical reporting practices lies with the single Services and the AHU remains the Army point of contact for any issues that may arise in relation to this. The guidance in JSP 539 continues to set the standards for best practice in the prevention of heat illness, but its effective application must be reviewed across the range of contemporary training and operational settings if reductions in morbidity are to be achieved and sustained in the Future Force.

Acknowledgements Notifications to the AHU were collated by Ms Sue Shelley, SO2 Healthcare Governance and Assurance, Headquarters Support Command, Aldershot, and Mr Alan Tidy, SO3 Medical Health Information, Army Health Unit, Army Medical Directorate, Camberley. Lt Col (Retd) RJL Fellowes, SO1(A) Accident Investigator, Army Headquarters, LAIT, Andover, gave permission for use of anonymised data from the AINC heat illness reporting database and provided commentary during the development of the manuscript.

Contributors MJS is responsible for the overall content as guarantor. All authors meet the authorship criteria endorsed by BMJ: substantial contributions to the conception of the work; drafting and revising the work critically for important intellectual content; final approval of the version to be published; agreement to be accountable for all aspects of the work in ensuring that questions related to the accuracy or integrity of any part of the work are appropriately investigated and resolved.

\section{Competing interests None.}

Provenance and peer review Not commissioned; externally peer reviewed.

Open Access This is an Open Access article distributed in accordance with the Creative Commons Attribution Non Commercial (CC BY-NC 4.0) license, which permits others to distribute, remix, adapt, build upon this work non-commercially, and license their derivative works on different terms, provided the original work is properly cited and the use is non-commercial. See: http://creativecommons.org/ licenses/by-nc/4.0/

\section{REFERENCES}

1 Headquarters of the Surgeon General. Joint Service Publication 539 version 2.4. Climatic illness and injury in the Armed Forces: Force Protection and initial medical treatment. August 2014

2 The Reporting of Injuries, Diseases and Dangerous Occurrences Regulations, 2013.
3 MOD Health and Safety Statistics Annual Report 2007/08-2012/13. https://www. gov.uk/government/uploads/system/uploads/attachment_data/file/279987/2012-13. pdf (accessed 13 Nov 2014).

4 Dickinson JG. Heat illness in the services. J R Army Med Corps 1994;140: $7-12$.

5 Finnegan TP. Heat illness in the services. J R Army Med Corps 1994;140:161-2.

6 Bricknell M. Heat illness: a comparison between UK and Cyprus reports. J R Army Med Corps 1996:142:59-61.

7 Burgess JE. Analysis of Y listings and medical discharges of officer Cadets at RMAS from January 1994 to May 1997, with actions to prevent injuries. J R Army Med Corps 1998;144:152-5.

8 Booker RJ, Bricknell MC. Heat illness—recent developments. J R Army Med Corps 2002:148:11-18.

9 SAS selection deaths: Soldiers died from 'overheating'. http://www.bbc.co.uk/news/ uk-wales-27765567 (accessed 13 Nov 2014).

10 Bricknell M. Prevention of Heat Illness in Iraq. In: Maintaining hydration: issues, guidelines, and delivery. http://natorto.cbw.pl/uploads/2004/7/MP-HFM-086-\$ ALL. pdf (accessed 13 Nov 2014).

11 Hunt PA, Smith JE. Heat illness. J R Army Med Corps 2005;151: $234-42$.

12 National Audit Office. Treating injury and IIIness arising on military operations (HC 294). London: The Stationery Office, 2010.

13 Connor $\mathrm{P}$, Hutley E, Mulcahy HE, et al. Enteric disease on Operation HERRICK. J R Army Med Corps 2013;159:229-36.

14 Armed Forces Health Surveillance Center (AFHSC). Update: heat injuries, active component, U.S. Armed Forces, 2013. MSMR 2014;21:10-13.

15 UK armed forces quarterly personnel report: index. https://www.gov.uk/government/ collections/uk-armed-forces-quarterly-manning-report-statistics-index (accessed 13 Nov 2014).

16 TSP7—UK Reserve Forces and Cadets 1 April 2013. https://www.gov.uk/ government/uploads/system/uploads/attachment_data/file/280401/2013.pdf (accessed 13 Nov 2014).

17 Bricknell MC, Wright LA. EX SAIF SEREEA II—the field hospital clinical report. J R Army Med Corps 2004;150:252-5.

18 Bricknell M. Prevention of Heat Illness in Iraq. In: Maintaining hydration: issues, guidelines, and delivery. http://www.rta.nato.int/Pubs/RDP.asp? RDP=RTO-MP-HFM-086 (accessed 1 Sep 2014)

19 Bolton JP, Gilbert PH, Tamayo C. Heat illness on Operation Telic in summer 2003: the experience of the Heat Illness Treatment Unit in northern Kuwait. J R Army Med Corps 2006;152:148-55

20 Day TK, Grimshaw D. An observational study on the spectrum of heat-related illness, with a proposal on classification. J R Army Med Corps. 2005;151:11-18.

21 Grainge $\mathrm{C}$, Heber $\mathrm{M}$. The role of the physician in modern military operations: 12 months experience in southern Iraq. J R Army Med Corps 2005;151: $101-4$.

22 World MJ, Booth TC. Iraq: the environmental challenge to HM land forces. Clin Med 2008:8:399-403.

23 O'Shea MK, Wilson D. Respiratory infections in the military. J R Army Med Corps 2013;159:181-9

24 DGAMS. Annual Report on the Health of the Army, 2013/14

25 Birmingham climate. http://www.metoffice.gov.uk/public/weather/limate/gcqdsfz6w (accessed 13 Nov 2014).

26 Heatwave linked to deaths of soldiers in Brecon Beacons. http://www.theweek.co. uk/uk-news/54125/

brecon-beacons-deaths-military-training-high-temperature-sas-mod (accessed 13 Nov 2014).

27 July heatwave. http://www.metoffice.gov.uk/education/8789 (accessed 13 Nov 2014).

28 Annual 2013. http://www.metoffice.gov.uk/climate/uk/summaries/2013/annual (accessed 13 Nov 2014).

29 Bricknell M. For debate: the operational patient care pathway. J R Army Med Corps 2014:160:64-9.

30 Embedding climate resilience in health \& safety management. https:/www.gov.uk/ government/uploads/system/uploads/attachment_data/file/33491/20121019IN06_ 12EmbeddingClimateResilinHSFU.pdf (accessed 13 Nov 2014).

31 Global Strategic Trends out to 2045. https://www.gov.uk/government/uploads/ system/uploads/attachment_data/file/348164/20140821_DCDC_GST_5 Web Secured.pdf (accessed 13 Nov 2014). 